\title{
The Use of Edmodo Application System to Increase Motivation for Learning English in the Second Semester of English Department at Madura Islamic University
}

\author{
Linta Wafdan Hidayah ${ }^{1}$, Samsi Rijal ${ }^{2}$, Rahmawati Ardila ${ }^{3}$ \\ Universitas Islam Madura \\ JL. PP. Miftahul Ulum Bettet, Pamekasan 69351, Madura \\ Email: missalindan@gmail.com ${ }^{1}$; samsirijal1983@ gmail.com ${ }^{2}$, taylorrayyan@ gmail.com ${ }^{3}$
}

\begin{abstract}
The use of technology in learning English is very important in today's modern era which is fully digital and electronic. Edmodo is one application of technology that can be used in the process of teaching and learning activities, also useful in learning English. Edmodo application can increase motivation to learn English and balance the development of an era that is completely sophisticated and fully uses electronic media technology. English learning in the second semester is the object of research and use of Edmodo system because second-semester students are considered to be still transitioning to emotional change so they need additional guidance in learning. The use of Edmodo is very useful for the second-semester students because they can discuss and share further online both with the lecturer and classmates. To support this research, researchers used descriptive qualitative. Edmodo is a developing application technology is very useful and important as a tool to assist lecturers in facilitating teaching and learning activities. This research focuses on the role of using Edmodo application in learning English to improve their learning skills and motivation of course.
\end{abstract}

Keyword: Edmodo, application, improve, learning English 


\begin{abstract}
Abstrak
Penggunaan teknologi dalam pembelajaran Bahasa Inggris sangat penting di era modern saat ini yang sepenuhnya menggunakan media digital dan elektronik. Edmodo adalah salah satu aplikasi teknologi yang dapat digunakan dalam proses kegiatan belajar mengajar, yang juga berguna dalam kegiatan belajar mengajar bahasa Inggris. Aplikasi Edmodo dapat meningkatkan motivasi untuk belajar bahasa Inggris dan menyeimbangkan perkembangan era modernitas yang benar-benar canggih dan sepenuhnya menggunakan teknologi media elektronik. Penggunaan sistem Edmodo dalam proses kegiatan belajar mengajar bahasa Inggris di semester kedua prodi Pendidikan Bahasa Inggris Universitas Islam Madura adalah objek penelitian ini. Tak hanya itu, mahasiswa semester dua masih dianggap transisi perubahan emosional dari masa sekolah sehingga mereka membutuhkan bimbingan dan motivasi lebih ekstra dalam proses pembelajaran. Penggunaan Edmodo sangat berguna bagi mahasiswa semester kedua karena mereka dapat berdiskusi dan berbagi materi pelajaran lebih lanjut secara online baik dengan dosen maupun teman sekelasnya. Untuk mendukung penelitian ini, peneliti menggunakan deskriptif kualitatif. Pengembangan tekhnologi aplikasi Edmodo yang sangat penting dan berguna sebagai alat media untuk membantu dosen dalam memfasilitasi kegiatan belajar mengajar. Penelitian ini berfokus pada peran menggunakan aplikasi Edmodo dalam belajar bahasa Inggris untuk meningkatkan keterampilan belajar dan motivasi mereka.
\end{abstract}

Kata kunci: Edmodo, Aplikasi, Peningkatan, Pembelajaran Bahasa Inggris 


\section{Introduction}

Language is an important tool for humans to communicate with others. in addition, language is used to convey their ideas and opinions in opinions. English is an international language and becomes the second language in Indonesia. Moreover, English as an important language and become material subject in field of education. So, many students have problem to communicate and learn in English subject.

Student motivation is one of the important issues in higher education, this is because it relates to the importance of the academic performance of the teaching profession in teaching and learning activities (Afzal: 2010: 80). Hanrahan (1998) argues that all student activities in the classroom are actually underlined and influenced by the motivation of lecturers in teaching and learning activities in class, especially in motivating the spirit of learning, especially learning foreign languages. Providing learning motivation for students is very important for the smooth learning process. Therefore learning motivation is one of the driving factors for students to learn and complete assignments given by the teacher or lecturer (2008: 3 ).

Learning motivation is not only needed at the school level such as elementary school, junior high school and senior high school. but learning motivation is also very necessary for students, especially students who happen to come from villages with a dialectal language are still mixed with their respective regional languages and enthusiasm for learning is still minimal, especially for second-semester students who are still emotional, even transitioning from high school.

Here, the researcher conducts her research in the second semester of English education department at Madura Islamic University. Most of them who has less motivation to learn English, it can be seen when the student of second semester felt bored and looks sleepy in the class. The researcher considered that it is necessary to use the technique of learning English in order to make students feel more motivation. To motivate students' enthusiasm for learning, researchers use the Edmodo system application. Edmodo application is considered to be very effective and in line with the development of the 


\section{JOURNAL OF LANGUAGE, LITERATURE, AND TEACHING}

Vol. 1 No. 3, December 2019, pp. 24 - 37

https://doi.org/10.35529/jllte.v1i3.24-37

modern era and sophisticated with all technologies in various fields, as well as in education.

Edmodo is an educational network tool that aims to facilitate teachers to help them connect and communicate more intensively with students and even with parents. with Edmodo application or website, teachers can share content in the form of pdf, word and ppt files, videos and online homework (https://www.whatiselt.com/singlepost/2018/01/28/What-is-Edmodo). Teachers are required to create an account at Edmodo before creating a class group on Edmodo. Not only that, Edmodo can be linked with other electronic media accounts such as Google, email, etc. But the information on this Edmodo is privacy, only members of the group can find out the contents of the Edmodo group account content. One of the benefits of using Edmodo is that students and parents or guardians of students can share information and learn about online teaching and learning courses. they are also required to create an email account first. after that they are required to enter their names and create a password and class code obtained from the teacher concerned. This group code is obtained automatically when creating a new group.

Edmodo is a technology platform in learning that is based on technological sophistication and social networking that can be used for academic practitioners such as lecturers, teachers, students and even parents can also play a role in it and know the course of learning activities so they can know the development of children's learning. Edmodo was first launched by Nic Borg and Jeff O'hara at the end of 2008. Edmodo is one of the elearning programs implemented in a learning system that is efficient, fun, easy to use and can balance the development of the era using technological sophistication. Edmodo also became one of the fastest-growing social networks in its use in early 2011, this is evidenced by the presence of more than 1 million Edmodo users. even in 2015 grew up to 50 million Edmodo users from various countries, not least the users of education practitioners in Indonesia.

Edmodo is very useful in helping the process of teaching and learning activities. Edmodo has a display design similar to the display design on social media like Facebook. With Edmodo application, teacher/lecturer can more easily send learning materials, grades, assignments, and quizzes to students. Not only in the process of teaching and learning 


\section{JOURNAL OF LANGUAGE, LITERATURE, AND TEACHING \\ Vol. 1 No. 3, December 2019, pp. 24 - 37 \\ https://doi.org/10.35529/jllte.v1i3.24-37}

activities between students and teachers as a facility for the smooth teaching and learning process between teachers and students. Even teachers can use the Edmodo application group so they can share experiences in teaching and learning experiences. Edmodo application has many benefits for education field.

The following are some of the benefits of Edmodo's application system in the field of education, especially teaching and learning activities, which are as follows:

- Edmodo is an easy way to communicate and discuss very efficiently between teachers, students and even parents.

- By using the Edmodo application, students can easily interact and discuss with each other which is monitored directly by the teacher or tutor.

- Not only that, of course, Edmodo application provides opportunities and comfort for parents and students themselves interact more intensively with their teachers.

- As one of the right places to carry out daily tests and quizzes easily and can be done with online access.

- In addition, with the use of the Edmodo application, teachers can certainly provide teaching materials such as documents in the form of videos, photos, words, pdfs, ppts, even some questions and the continuity of efficient learning to students.

- In addition, teaching materials from the teacher to students that can later be downloaded directly by students easily and efficiently.

- By using Edmodo's application, parents can also contribute by monitoring the development of their child's direct learning.

- Provide the broadest possible space and time for teachers to provide questions or teaching material wherever and whenever which is not limited to only in class and during class time.

- In addition, provide fresh air to students so that they do not get bored quickly in accepting lessons from the teacher because students are also given the opportunity to be able to hold more useful gadgets.

Actually, there are several features available and offered by Edmodo application to support the process of learning activities between teachers and students. The researcher 
will explain the features below provided by Edmodo application (https://www.nesabamedia.com/pengertian-manfaat-dan-fitur-edmodo/):

\section{Polling}

Polling is a feature in the Edmodo application that can only be used by teachers. The use of the voting feature is used by teachers to find out student responses about something offered by the teacher. This polling feature is the best way to get feedback between teachers and students, usually used when giving assignments. Polling can also be useful for students to understand the subject matter they have just learned.

\section{Gradebook}

This guidebook feature is similar to notebooks for students. With this telephone book feature, students get grades from the teacher manually or automatically.

This feature gives the teacher space to manage the assessment of student learning outcomes as a whole and can be exported to CSV files. The teacher is the holder of full power to access the grade book features while students can only see a summary of the overall assessment provided by the teacher.

Not only that, the assessment notes can be arranged quickly by the teacher in Edmodo's application. The teacher can also add the assessment period to the Progress Book in this Edmodo application precisely in this number book feature easily, can add assignments and grades, monitor the grades of each student. make it easier for teachers and parents to monitor the progress of student learning development and find out the ranking of students easily and efficiently.

\section{Files and Links}

This file and link feature functions to send notes using file attachments and links in the form of documents, .ppt, .xls, .pdf, and others. Sometimes the teacher provides additional learning material so that it is more acceptable and understood by students. This is where the benefits of using the File and Links feature are on Edmodo. teachers can upload videos, images, text, or whatever their form easily and 
quickly, so they can provide their own enthusiasm in curiosity more about the learning material delivered, and provide a new atmosphere that is not monotonous just by teaching only in class.

\section{Quiz}

as with the number book feature, this Quiz Feature can only be made by the teacher concerned who has the authority, students do not have the authority to make quizzes, they can only work on quiz questions that have been given by their teacher. This quiz is conducted by teachers to give and know online evaluations to students in the form of multiple-choice questions, as well as full descriptions.

By using this Edmodo application, online quizzes can follow the era of technology, because teachers can add pictures or even videos as additional questions in the quiz. Not only that, teachers can also save quiz questions in the Library feature on Edmodo application, so they can be used again in the next class. students can also know the value directly from the results of the quiz work so students can find out whether they should refine or rework the quiz or not.

\section{Library}

With this feature, teachers can upload teaching materials such as study materials, pictures, presentations, videos, and even reference sources. This feature serves to accommodate an unlimited number of files and links and can also arrange according to your wants and needs. in addition, these documents can be accessed anywhere by the teacher.

\section{Assignment}

This feature can be used by teachers to give students online assignments. the advantage of this feature is that it is equipped with a file attachment feature, deadlines, in the form of document files (pdf, doc, Xls, ppt). in this assignment 
feature there is a "Play" button on the sending of assignments that can be used by the teacher that students have completed their assignments.

\section{Parent Code}

When students create a student account on Edmodo, they automatically will also get a Parent Code that can be used by their parents to create a parent-specific account. the benefits of this parent code are being able to monitor activities within the group that are being followed by students, and being able to monitor the learning process of the account. Students' parents can click on their child's class/group name on Edmodo or can ask the teacher to get the group code.

\section{Award Badges}

The award badge feature is usually used by teachers, to give appreciation to students. Badges are given by the teacher as a positive track record for students. usually, the teacher gives a badge of appreciation to high-achieving students who have done good quizzes and assignments. This badge can also be a motivation for students to perform various tasks better.

\section{Methods}

Researchers used descriptive qualitative research methods in this study. Satori (2011: 23) argues that researchers conduct qualitative research because they want to explore the phenomena of the learning process cannot be quantified and is described as a formula for a recipe, a process work steps, notions of diverse concepts, and others. In addition, Sugiono (2012: 9) also stated the research qualitative as a research method used to examine the condition of natural objects and results qualitative research emphasizes more meaning than generalization, data analysis is inductive or qualitative, and researchers are the main instruments.

Sugiono (2009: 216) argues that the sample in the study does not use respondents' qualitative data, but as participants or resource persons, informants, even friends and teachers in research. In addition, the sample in this study was descriptive qualitative also not called a statistical sample, but a theoretical sample, because of purpose qualitative 
research is to produce a theory whether the theory is useful or not for users. Determination of the sample conducted during this research.

Based on the opinions of some of the experts above about qualitative research, it can be drawn the conclusion that qualitative descriptive research is a series of activities in order to obtain data that is real in conditions certain. Here, the researcher using descriptive qualitative research methods because of this research exploring the phenomenon of the use of Edmodo applications in the process of teaching and learning activities to motivate student enthusiasm for learning. Besides this research is also nature the inductive and the results emphasize the student's goals more motivated and enthusiastic in learning activities guided by a lecturer. The object of his research, the researchers conducted research on the campus of the Madura Islamic University, precisely the second semester of the English Education Department.

Researchers in this study use triangulation of sources to determine the validity of the data obtained. The data that has been obtained will be analyzed using qualitative descriptive data analysis based on the theory of Cresswel (2015), namely reading (scraping), data management, data description, interpretation of data clarification, visualization of data presentation. This study was used to determine whether the use of Edmodo application can increase student enthusiasm in learning English.

\section{Result}

Based on data collected through the questionnaire, researchers get the results of the study as follows. First, all participants (100\%) argue that the use of the Edmodo application can make an impact positive in the learning process activities of all courses that are in English education majors. because the use of the Edmodo application in their learning process so far is something new for participants, as revealed by AMT (not real name) following:

"Using this application (Edmodo, meaning) is useful to add/hone my knowledge, especially the combination of technology in education known as e-learning. Not only that, I got new experiences as material to educate my future students " 


\section{JOURNAL OF LANGUAGE, LITERATURE, AND TEACHING}

Vol. 1 No. 3, December 2019, pp. 24 - 37

https://doi.org/10.35529/jllte.v1i3.24-37

The process of learning activities that use this application (Edmodo application, it means) really help students better understand in digesting the material provided by the lecturer. and all teaching material from lecturers can be neatly stored in Edmodo files so that it can be reused later when students become teachers later.

In addition, learning activities using the Edmodo application is useful as a medium for students to convey their opinions and problems experienced by students in the learning process activities so far and can also be private, therefore students tend to be more open in raised the problem, so they are more motivated and motivated in learning. students no longer feel ashamed to express their opinions and discuss with others. so as to create better communication between teacher and student. this was stated by CY and MT (pseudonym) as follows:

CY: "using this Edmodo application is very influential on my psychology because with this Edmodo application we are can remember in writing because the files are arranged more neatly and can also convey problems to the lecturer we get during the learning process. In addition, using the Edmodo application during lessons can make our (student) communication closer to students the lecturer in question ".

MT: "The existence of this Edmodo can write problems and the difficulties I face in learning because sometimes I feel embarrassed and lack of confidence when asking directly in class ".

The second result, a number of $95.65 \%$ of participants had opinions and positive feelings towards learning activities in English using Edmodo's application. Although there are some students who say that using the Edmodo application at first is a bit complicated, but does not avoid the benefits of using the Edmodo application for them, as stated by TP that the initial use of the Edmodo application is complicated but there are many benefits and are more relaxed in learning but quality. This was also conveyed by JY who stated that using this Edmodo application initially felt complicated, but in reality it was very good to feel the benefits and could be used again to teach references. In addition, HY revealed that:

"This new innovation from lecturers who support the course, may not have been done by other courses this method is a new breakthrough." 
While DA revealed the interesting side of using this Edmodo application, that it was more effective and attracted students to be more enthusiastic in the learning process activities.

The third result, participants expressed opinions about the benefits of using this Edmodo application in the learning process, namely: (1) making it easy to remember teaching materials $(45.65 \%)$, (2) knowing the development of self-ability in learning (36.96\%), ( 3) provide self motivation in learning English (19.56\%), (4) better understand teaching materials provided by lecturers $(13.04 \%)$, (5) provide new innovations in learning using gadget technology (17.49) and (6) Add insight and experience (6.52\%).

\section{Discussion}

In general, the results of the study indicate that using Edmodo application in the process of learning English has a positive effect on motivating students in the spirit of learning English and has a significant influence. One of the things that motivate and motivates this is because the activity of using the Edmodo application helps students to review the material that has been given by the lecturer so that it is easier to remember the material, and has some teaching material obtained directly from lecturers who support the course. And can provide new innovations in learning activities that have been monotonous only limited to lectures and presentations in class that make students more quickly bored and sleepy during lesson activities. Edmodo application is one of technology system that can use in education field.

They are the advantages of technology applications in education:

\section{Technology can help teachers when teaching-learning material}

This can be an easy tool and way for teachers to deliver teaching material to students. By using technology in the learning process, teachers can convey subject matter very easily and effectively. Teachers who teach using technology will usually more easily achieve goals in the process of teaching and learning activities.

\section{Technology will trigger teacher creativity}

That can create teacher creativity and create new innovations because teachers can be more creative in creating teaching methods.

3. Technology helps students learn 
The implementation of technology in the process of teaching and learning activities will make students more interested and enthusiastic about the lesson, and students do not get bored quickly in receiving teaching material.

4. Technology can create learning activities that are more interesting and innovative

With technology, teachers can create a more interesting and not boring learning atmosphere, because students can learn with interesting learning methods.

5. Technology makes students have broader insights

Students who use technology applications correctly will have more extensive knowledge than students who don't use technology because they can get information updates or world developments quickly.

From the explanation above, it has been revealed that using Edmodo application in the learning process as a form of using technology in education. In addition, based on the results of a questionnaire conducted by researchers in this study can be concluded through the diagram below

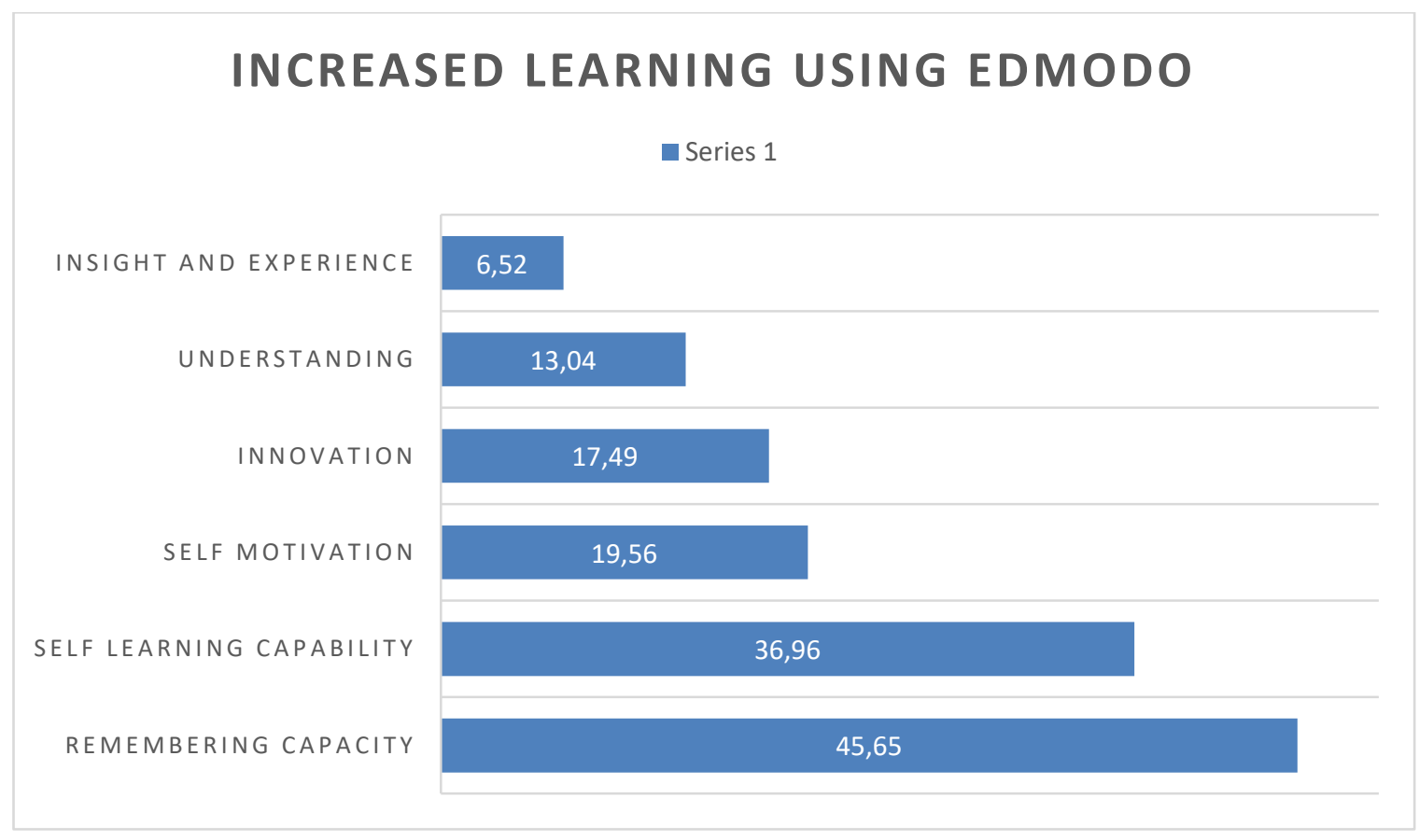

Judging from the exposure to the benefits and features of the Edmodo application, Edmodo is a very appropriate and efficient tool or container to use as an online learning 
medium. In addition, Edmodo can also facilitate teaching and learning activities between teachers and students who are more creative, innovative and fun because it is not boring. so that teachers and students as academic practitioners can benefit from the benefits of using the Edmodo application.

The teacher becomes easier to provide teaching material to students. Document files are more organized and can be reused when needed when teaching again. It is also easier for teachers to find out and monitor each student's track record of progress. Meanwhile, from the student's side, learning to sit is not monotonous and boring always in a class by listening to the teacher's lecture explaining the teaching material that makes students sleepy. Students become more understanding of the lesson by adding files or links provided by the teacher. Students can be more motivated by giving badges from the teacher. Likewise, parents have a stake in being able to monitor the development of their children in the learning process with the teacher. 


\section{References}

Creswell, J. W. (2014). Research Design: Qualitative, Quantitative and Mixed Methods Approaches (4th ed.). Thousand Oaks, CA: Sage.

Creswell, J. (2015). Educational Research: Planning, Conducting and Evaluating Quantitative and Qualitative Research. New York: Pearson.

Satori, Djam'an; Aan Komariah. 2011. Metode Penelitian Kualitatif. Bandung: Alfabeta.

Sugiyono. 2012. Metode Penelitian Kuantitatif Kualitatif. Bandung: Alfabeta.

Sugiyono. 2009. Metode Penelitian Bisnis (Pendekatan Kuantitatif, Kualitatif, dan R\&D). Bandung: Alfabeta

Andriyani, Fitria Dwi and Eka Novita Indra. 2017. Kontribusi Penggunaan Jurnal Belajar Pada Pembelajaran Matakuliah Permainan Bolabasket. UNY: Jurnal Cakrawala.https://media.neliti.com/media/publications/84636-nonecdcb897c.pdf

Zakaria. 2019. Tentang Edmodo : Pengertian, Manfaat, dan Fitur-Fiturnya yang Wajib Anda Ketahui https://www.nesabamedia.com/pengertian-manfaat-dan-fitur-edmodo/

Zakime, andreia. 2018. What is Edmodo?. https://www.whatiselt.com/single-

post/2018/01/28/What-is-Edmodo 